\title{
Crust-mantle coupling revisited: The Archean Slave craton, NWT, Canada
}

\author{
H. Helmstaedt \\ Dept. of Geological Sciences and Geological Engineering, Queen's University, Kingston, Ontario, \\ Canada
}

Present geological and geophysical data, including information from the kimberlitic lower crustal and upper mantle sample, are consistent with a modified version of an accretionary model (1989), viewing the Slave Province as a tectonic collage consisting of a Mesoarchean microcontinental nucleus enlarged by the addition of a number of Neoarchean juvenile terranes. The Mesoarchean nucleus is a composite terrane, referred to as Central Slave superterrane (CSST), representing a fragment of an earlier craton that evolved between ca. 4.0 and 2.85 Ga before breaking up at the end of the Mesoarchean. It is manifest as scattered occurrences of metamorphosed basement gneisses in a N-S trending zone through the westcentral and northwestern parts of the province. Its presence is also discernable by Mesoarchean inheritance in isotopic signatures of Neoarchean intrusive rocks and in lower crustal xenoliths from kimberlites. Three Neoarchean tectonic domains were accreted to the CSST from the east. In the northernmost part of the province, the eastern margin of the CSST is in structural contact with ca. 2708-2670 Ma juvenile arc-like volcanic and sub-volcanic rocks of the Hackett River terrane (HRT), with suturing thought to have begun at ca. 2650 Ma. Farther south, the CSST and HRT are separated by metaturbidites and volcanic slivers of the Contwoyto terrane (CT), an accretionary prism overlying the eastern part of the CSST. East of the northeastern part of the HRT is the Neoarchean Bathurst Block (BB) whose terrane status is still uncertain, though the juvenile and bimodal character of well-preserved volcanic belts in the northern part of the BB suggests a back-arc-basin setting with respect the Hackett River arc. Suturing at the western boundary of the CSST with the juvenile Neoarchean Snare River terrane (SRT) is thought to have occurred between ca. 2630 and $2620 \mathrm{Ma}$. The suture is cryptic as a result of late structural and intrusive overprinting, but the subsurface geometry of the terrane boundary is constrained by LITHOPROBE seismic reflection data suggesting that Mesoarchean basement of the CSST forms a wedge-shaped "intra-Archean indenter" pointing westwards into the Neoarchean SRT (van der Velden, 2007).

Whereas accretion of the Neoarchean juvenile terranes to the CSST took place in an environment of E-W convergence (present coordinates), the first postaccretion granitoid intrusive rocks, belonging to the arc-like, ca. 2630-2620 Ma Defeat magmatic suite, form a northeast-trending belt in the southern part of the Slave Province which cuts across terrane boundaries. The belt is more or less parallel with inferred trends of pre- to syn-Defeat suite cleavagerelated folds (" $\mathrm{D}_{1}$ ") in metaturbidites of the Yellowknife Supergroup, suggesting that Defeat-suite magmatism took place in an arc environment during NW-SE convergence (Davis and Bleeker, 1999). E-W convergence was re-established during a pan-Slave regional $\mathrm{D}_{2}$ event resulting in E-W shortening, crustal thickening, regional low-P, high-T metamorphism and a regional "granite-bloom" between ca. 2610 and 2590 Ma. Pre-D2 structures were overprinted and in part obliterated by a northerly-trending structural grain. Metamorphism followed a classic clockwise P-T-t path, with peak-metamorphic pressures (up to $>6$ kbar) recorded in the granulite-facies Snare domain and structural culminations of the Contwoyto and Hackett River terranes, where greatest crustal thickening had occurred during terrane accretion.

Following the discovery of diamondiferous kimberlites on the Slave craton, their upper mantle sample was studied extensively to determine composition and structure of the lithosphere as well as to establish the age of diamond formation and crust-mantle coupling. Based on regional variations in the chemistry of mantle-derived garnet xenocrysts from till samples, Grütter et al. (1999) inferred the existence of three ENE-trending lithospheric domains with marked differences in depletion of peridotite bulk compositions. A central domain, which is characterized by an abundance of ultra-depleted garnets, includes the Lac de Gras kimberlite field, where the presence of an ultra-depleted harzburgite layer (UDL) was recognized also from studies of xenoliths and garnet concentrates from kimberlites (Griffin et al., 1999b; Pearson et al., 1999). A northern domain is indicated by a sharp drop in abundance of G-10 garnets and an increase in the number of eclogitic garnets. The boundary with the southern domain is less sharp, but also marked by a significant decrease in G-10 garnets and an increase in eclogitic garnets. Some extremely high-Cr garnets occurring in exploration sample in the southern domain are found also in the Snap Lake and CL-25 kimberlites (McLean et al., 2001; Pokhilenko et al., 1997). Because a N-S cross-section through the Slave Province lithosphere, constructed from upper mantle columns sampled by widely distributed kimberlites (Kopylova and Caro, 2004), is broadly compatible with the observations of Grütter et al. (1999), the notion of a late Archean, north-northeast trending mantle-domain 
structure has become widely accepted (see also Davis et al., 2003).

As the inferred central, ENE trending, ultra-depleted mantle domain sits astride the N-S trending terrane boundaries, but is sub-parallel to "D1" structural trends and the regional distribution of Defeat-age arc-like plutonic rocks in the southern Slave Province, Grütter et al. (1999) concluded that the crust and underlying lithospheric mantle were coupled in the Neoarchean along northeast-trending zones. After the first Mesoarchean Re-Os model ages were presented from Slave peridotite xenoliths (e.g., Aulbach et al., 2001), Davis et al. (2003b) considered it a paradox that extensive Neoarchean plutonism and low-P, high-T metamorphism in the crust of the Slave Province should have developed above a previously stabilized, thick Mesoarchean lithospheric root (see also Canil, 2008). They argued that such a root was absent under the CSST at ca. 2.7 Ga, probably as a result of lithosphere delamination, and they suggested further that the Neoarchean crustal evolution of the Slave crust and the apparent ENE domain structure in the Slave lithosphere could be reconciled only if the latter was assumed to have developed relatively late in the Neoarchean orogenic cycle. A corollary of the late inferred crust-mantle coupling is that diamond formation is thought to have occurred at the earliest in the latest Archean, within only slightly older lithosphere (Davis et al., 2003b). Other mechanisms to account for the Neoarchean "granite-bloom" include the impact of a mantle plume (Griffin et al., 1999a) and heat transfer from the mantle by a process of lithosphere inversion rather than lithosphere delamination (Percival and Pysklywec, 2007).

In the present paper, it is suggested that a Mesoarchean lithospheric root was coupled to the Mesoarchean crust of the CSST long before accretion of the adjacent juvenile Neoarchean terranes. The remnants of this root are preserved as the harzburgitic layer (UDL) which is thickest (up to $\sim 150 \mathrm{~km}$ ) and most depleted where it is buried under the allochthonous Contwoyto terrane, showing the highest G-10 garnet and harzburgitic (Ptype) diamond contents under the central part of the Lac de Gras kimberlite field. The great antiquity of the root is suggested by ca. 3.5 Ga sulfide inclusions in Ptype diamonds from the UDL (Westerlund et al., 2006) and ca. 3.3 Ga sulfide inclusions in olivine from the lower, less depleted layer (Aulbach et al., 2004). Coupling of the root to overlying crust is suggested by lower crustal granulite-facies xenoliths with $>3 \mathrm{Ga}$ protoliths ages in the Lac de Gras kimberlites (Davis et al., 2003a) and by the emplacement of ca. $3.35 \mathrm{Ga}$ tonalites, interpreted as melting products of subducted oceanic lithosphere (Yamashita et al., 2000), into the crust of the CSST.

The peridotitic shallow mantle, parts of which are in the graphite stability field (Jones et al., 2003) shows greater chemical depletion than the deeper portions of the lithosphere (Griffin et al., 1999a; Griffin et al.,
2004; Kopylova and Caro, 2004). However, as shown by Griffin et al. (2004), depleted Mesoarchean lithosphere is not restricted to the central zone of Grütter et al. (1999) but has survived as pockets in the otherwise strongly modified lithosphere of the northern Slave Province (e.g. Anuri kimberlite). Thus, the northeasterly-trending northern margin of the central domain of Grütter et al. (1999), marked by a sharp drop in abundance of G-10 garnets, is unlikely to represent the boundary of a primary mantle domain, but should be considered as a secondary feature caused by metasomatism and/or tectonic erosion of Neoarchean and Proterozoic age.

Major mantle domain boundaries under the Slave Province follow more northerly trends and are closely related to major tectonic terrane boundaries. As seen on the cross-section below, the eastern margin of the Mesoarchean root coincides with the eastern boundary of the buried CSST under the adjacent Neoarchean Contwoyto and Hackett River terranes. It is parallel to the NNW trending cryptic suture with the juvenile Hackett River terrane and more or less corresponds with the eastern Neoarchean rifted margin of the CSST. The western limit of the Mesoarchean root is tectonic and related to collision of the Slave Province with adjacent Paleoproterozoic terranes. LITHOPROBE reflection seismic and teleseismic data have imaged eastward-dipping slabs of subducted Paleoproterozoic lithosphere that underplated the Slave Province from the west (Bostock, 1997; Bostock, 1998; Cook and Erdmer, 2005; Cook et al., 1999; Snyder et al., 2004) and tectonically eroded the western and central lower parts of the Mesoarchean harzburgitic root under the CSST. LITHOPROBE interpretations have now been corroborated by Paleoproterozoic ages for eclogite xenoliths from the Diavik and Jericho kimberlites (Heaman et al., 2006; Heaman et al., 2002; Schmidberger et al., 2005; Schmidberger et al., 2007). Massive Paleoproterozoic underplating thus stabilized remnants of the Archean root above it and caused downward younging of the lithosphere. At least part of the eclogitic (E-type) diamond budget of the central and northern Slave Province kimberlites is thought to have been derived from this underplated Paleoproterozoic component.

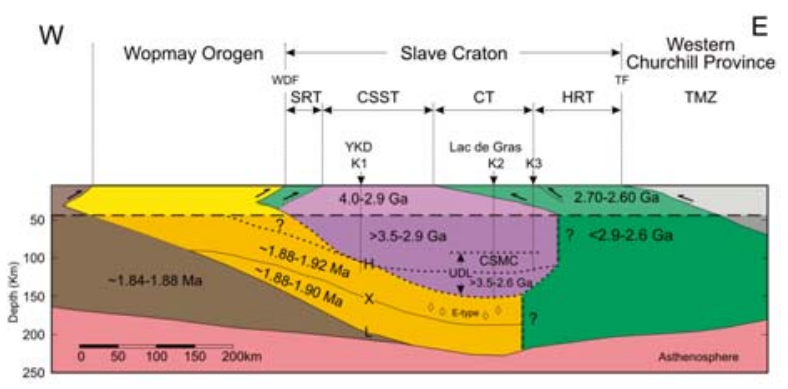

Cross-section through lithosphere of Slave Province showing remnants of Mesoarchean root (purple) of Central Slave superterrane (CSST) between Neoarchean lithosphere (green) in the east and Paleoproterozoic lithosphere (beige) in west and below. 
SRT-Snare River terrane; CT-Contwoyto terrane; HRT-Hackett River terrane.

\section{References}

Aulbach, S. et al., 2001. Re-Os isotope evidence for MesoArchean mantle beneath 2.7 Ga Contwoyto terrane, Slave craton, Canada: Implications for the tectonic history of the Slave craton. The Slave-Kaapvaal Workshop volume, Merrickville, Ontario (Sept. 59, 2001), Abstracts Volume.

Aulbach, S. et al., 2004. Mantle formation and evolution, Slave Craton: constraints from HSE abundances and Re-Os isotope systematics of sulfide inclusions in mantle xenocrysts. Chemical Geology, 208: 6188.

Bostock, M.G., 1997. Anisotropic upper-mantle stratigraphy and architecture of the Slave craton. Nature, 390: 392-395.

Bostock, M.G., 1998. Mantle stratigraphy and evolution of the Slave Province. Journal of Geophysical Research, 103: 21183-21200.

Canil, D., 2008. Canada's craton: A bottoms-up view. GSA Today, 18(6): 4-10, doi: 10.1130/GSAT01806A.1.

Cook, F.A. and Erdmer, P., 2005. An 1800 km cross section of the lithosphere through the northwestern North American plate: lessons from 4.0 billion years of Earth's history. Canadian Journal Earth Sciences, 42: 1295-1311.

Cook, F.A., van der Velden, A.J., Hall, K.W. and Roberts, B.J., 1999. Frozen subduction in Canada's Northwest Territories: Lithoprobe deep lithospheric reflection profiling of the western Canadian Shield. Tectonics, 18: 1-24.

Davis, W.J. and Bleeker, W., 1999. Timing of plutonism, deformation, and metamorphism in the Yellowknife Domain, Slave Province, Canada. Canadian Journal of Earth Sciences, 36: 11691187.

Davis, W.J., Canil, D., MacKenzie, J.M. and Carbno, G.B., 2003a. Petrology and U-Pb geochronology of lower crustal xenoliths and the development of a craton, Slave Province, Canada. Lithos, 71: 541-574.

Davis, W.J., Jones, A.G., Bleeker, W. and Grutter, H.S., 2003b. Lithosphere development in the Slave craton: a linked crustal and mantle perspective. Lithos, 71: 575-590.

Griffin, W.L. et al., 1999a. Layered mantle lithosphere in the Lac de Gras area, Slave craton: Composition, structure and origin. Journal of Petrology, 40: 705727.

Griffin, W.L. et al., 1999b. Lithosphere structure and mantle terranes: Slave craton, Canada. In: J.J. Gurney, J.L. Gurney, M.D. Pascoe and S.H. Richardson (Editors), Proceedings of the VIIth International Kimberlite Conference, Cape Town, pp. 299-306.

Griffin, W.L. et al., 2004. Lithosphere mapping beneath the North American plate. Lithos, 77: 873-922.

Grütter, H.S., Apter, D.B. and Kong, J., 1999. Crust-mantle coupling: Evidence from mantle-derived xenocrystic garnets. In: J.J. Gurney, J.L. Gurney, M.D. Pascoe and S.H. Richardson (Editors), Proceedings of the VIIth International Kimberlite Conference, Cape Town, pp. 307-313.

Heaman, L., Creaser, R.A., Cookenboo, H.O. and Chacko, T., 2006. Multi-stage modification of the northern Slave mantle lithosphere: Evidence from zirconand diamond-bearing eclogite xenoliths entrained in Jericho kimberlite, Canada. Journal of Petrology,, 47: 821-858.

Heaman, L.M., Creaser, R.A. and Cookenboo, H.O., 2002. Extreme enrichment of high field strength elements in Jericho eclogite xenoliths: a cryptic record of Paleoproterozoic subduction, partial melting, and metasomatism beneath the Slave Craton, Canada. Geology, 30: 507-510.

Jones, A.G. et al., 2003. The electrical structure of the Slave craton. Lithos, 71: 505-528.

Kopylova, M.G. and Caro, G., 2004. Mantle xenoliths from the southeastern Slave craton: Evidence for chemical zonation in a thick, cold lithosphere. Journal of Petrology,, 45: 1045-1067.

Kusky, T.M., 1989. Accretion of the Archean Slave Province. Geology, 17: 63-67.

McLean, R.C., Pokhilenko, L.N., Hall, A.E. and Luth, R.W., 2001. Pyropes and chromites from kimberlites of the Snap Lake area, southeast Slave craton: garnetization reaction of depleted peridotites at extreme deep levels of the lithospheric mantle. The Slave-Kaapvaal Workshop volume, Merrickville, Ontario (Sept. 5-9, 2001), Abstracts Volume.

Pearson, N.J. et al., 1999. Xenoliths from kimberlite pipes of the Lac de Gras area, Slave craton, Canada. In: J.J. Gurney, J.L. Gurney, M.D. Pascoe and S.H. Richardson (Editors), Proceedings of the VIIth International Kimberlite Conference, Cape Town, pp. 644-658.

Percival, J.A. and Pysklywec, R.N., 2007. Are Archean lithospheric keels inverted? Earth and Planetary Science Letters, 254: 393-403.

Pokhilenko, N.P. et al., 1997. Indicator minerals from the CL-25 kimberlite pipe, Slave Craton, Northwest Territories, Canada. Russian Geology and Geophysics, 38: 550-558.

Schmidberger, S.S., Heaman, L.M., Simonetti, A., Creaser, R.A. and Cookenboo, H.O., 2005. Formation of Paleoproterozoic eclogitic mantle, Slave Province (Canada): Insights from in situ $\mathrm{Hf}$ and $\mathrm{U}-\mathrm{Pb}$ isotope analyses of mantle zircons. Earth and Planetary Science Letters, 240: 621-633.

Schmidberger, S.S., Simonetti, A., Heaman, L.M., Creaser, R.A. and Whiteford, S., 2007. Lu-Hf, in situ Sr and $\mathrm{Pb}$ isotope and trace element systematics for mantle eclogites from the Diavik diamond mine: Evidence for Paleoproterozoic subduction beneath the Slave craton, Canada. Earth and Planetary Science Letters, 254: 55-68.

Snyder, D.B., Rondenay, S., Bostock, M.G. and Lockhart, G.D., 2004. Mapping the mantle lithosphere for diamond potential using teleseismic methods. Lithos, 77: 859-872.

van der Velden, A.J., 2007. Seismic reflection profiling of Neoarchean cratons. PhD Thesis, University of Calgary, 195 pp.

Westerlund, K.J. et al., 2006. A subduction wedge origin for Paleoarchean peridotitic diamonds and harzburgites from the Panda kimberlite, Slave craton: evidence from Re-Os isotope systematics. Contributions to Mineralogy and Petrology, 152: 275-294.

Yamashita, K., Creaser, R.A., Jensen, J.E. and Heaman, L., 2000. Origin and evolution of mid- to late-Archean crust in the Hanikahimajuk Lake area, Slave Province, Canada; evidence from U-Pb geochronological, geochemical and $\mathrm{Nd}-\mathrm{Pb}$ isotopic data. Precambrian Research, 99: 197-224. 